\title{
POSSIBLE CAVERN-FORMING ACTIVITY AT MILLENNIAL TIME SCALES AND ITS IMPACT ON VARIATIONS IN SUBMARINE CAVE ENVIRONMENTS AND HABITAT AVAILABILITY, OKINAWA, JAPAN
}

\author{
Akihisa Kitamura ${ }^{1 *}$, Chikako Tamaki ${ }^{1}$, Yosuke Miyairi², Yusuke Yokoyama², and Hideki Mori ${ }^{3}$
}

\begin{abstract}
We examined the spatial distributions and ${ }^{14} \mathrm{C}$ ages of sessile marine organisms in the submarine cave Ginama at Okinawa, Japan. The cave is the northernmost and only known submarine cave with an air chamber in the northwestern Pacific region. The upper limit of living individuals of the coralline sponges Acanthocaetetes wellsi and the bivalve Pycnodonte taniguchii in the cave is located at a depth of approximately $10 \mathrm{~m}$ relative to the surface of the pool in the cave. Low temperatures and low salinities prevent these organisms from colonizing water depths shallower than $10 \mathrm{~m}$. On the other hand, the upper limit of fossil individuals, dated between 5117 and $387 \mathrm{cal} \mathrm{yr} \mathrm{BP}$, is at a depth of $2.5 \mathrm{~m}$, implying that at present the influence of fresh water on the cave pool is stronger than it has been at other times in the past 5000 years. This increase in the flux of fresh water may be explained by continuous cavern-forming activities such as dissolution.
\end{abstract}

\section{INTRODUCTION}

A number of workers have recently used archival materials from submarine caves to reconstruct environmental changes during the late Quaternary (Antonioli et al., 2001; Kitamura et al., 2007, Yamamoto et al., 2008, 2009a). For example, oxygen-isotopic compositions of coralline sponges and micro-bivalves from submarine caves have been studied as proxies for palaeotemperature (Böhm et al., 2000; Haase-Schramm et al., 2003; Yamamoto et al., 2008, 2009b, 2010; Kitamura et al., 2013). In addition, the history of sea level changes has been examined using both speleothems and changes in faunal assemblages preserved in cave sediments (Dorale et al., 2010; Tuccimei et al., 2010; van Hengstum and Scott, 2011, 2012, van Hengstum et al., 2011).

However, few studies have examined temporal changes in faunal communities in submarine caves. In Mediterranean submarine caves, Chevaldonné and Lejeusne (2003) documented that populations of cold stenothermal species of mysids (Crustacea) were replaced by congeners of warmer affinities during a period of regional warming in the summers of 1997 and 1999. Parravicini et al. (2010) examined changes in sessile communities in a Mediterranean submarine cave using photographs taken in 1986 and 2004, revealing that massive numbers of organisms experienced high rates of mortality due to thermal anomalies during the summer heat waves of 1999 and 2003 and that these groups were replaced by encrusting organisms.

The northward-flowing tropical Kuroshio Current allows coral reefs to form in the Ryukyu Islands of southwestern Japan, northwestern Pacific (Fig. 1a). The islands extend from Tane-ga Island $\left(30^{\circ} 44^{\prime} \mathrm{N}, 131^{\circ} 00^{\prime} \mathrm{E}\right)$ in the northeast to Yonaguni Island $\left(24^{\circ} 27^{\prime} \mathrm{N}, 123^{\circ} 00^{\prime} \mathrm{E}\right)$ in the southwest. Many submarine limestone caves occur on the islands (Hayami and Kase, 1993). However, previous studies of changes in the communities of submarines caves have only considered millennial-scale variations in the species compositions of bivalves (Kitamura et al., 2007; Yamamoto et al., 2009a) and algal symbiont-bearing large benthic foraminifers (Omori et al., 2010) in Daidokutsu submarine cave (water depth, $29 \mathrm{~m}$ ) at Ie Island, Okinawa (Fig. 1a). In both studies, the species living in the innermost areas of the cave were seen to have become increasingly dominant over the past 7000 years, while those living near the cave entrances have declined in abundance. The studies concluded that the changes were caused by a decline in food supply and light intensity in the cave associated with the filling of cavities within the reef during at least the past 6500 years. However, temporal changes in the communities of sessile organisms in submarine caves have yet to be examined in the northwestern Pacific.

This study examined millennial-scale variations in the compositions of sessile marine faunal communities in the submarine cave Ginama at Okinawa, Japan (Fig. 1b-d). The cave is unique in being the northernmost and only known submarine cave with an air chamber in the northwestern Pacific region.

\section{Study Area}

The submarine cave Ginama occurs in Triassic limestone (Ishibashi, 1974) on the northernmost coast of Okinawa Island (Fig. 1b). The coastline is characterized

\footnotetext{
${ }^{1}$ Institute of Geosciences, Shizuoka University, Shizuoka, 422-8529, Japan

${ }^{2}$ Atmosphere and Ocean Research Institute, University of Tokyo, Chiba, 277-8564, Japan

${ }^{3}$ Division of Technical Service, Shizuoka University, Shizuoka, 422-8529, Japan

* Corresponding Author: seakita@ipc.shizuoka.ac.jp
} 

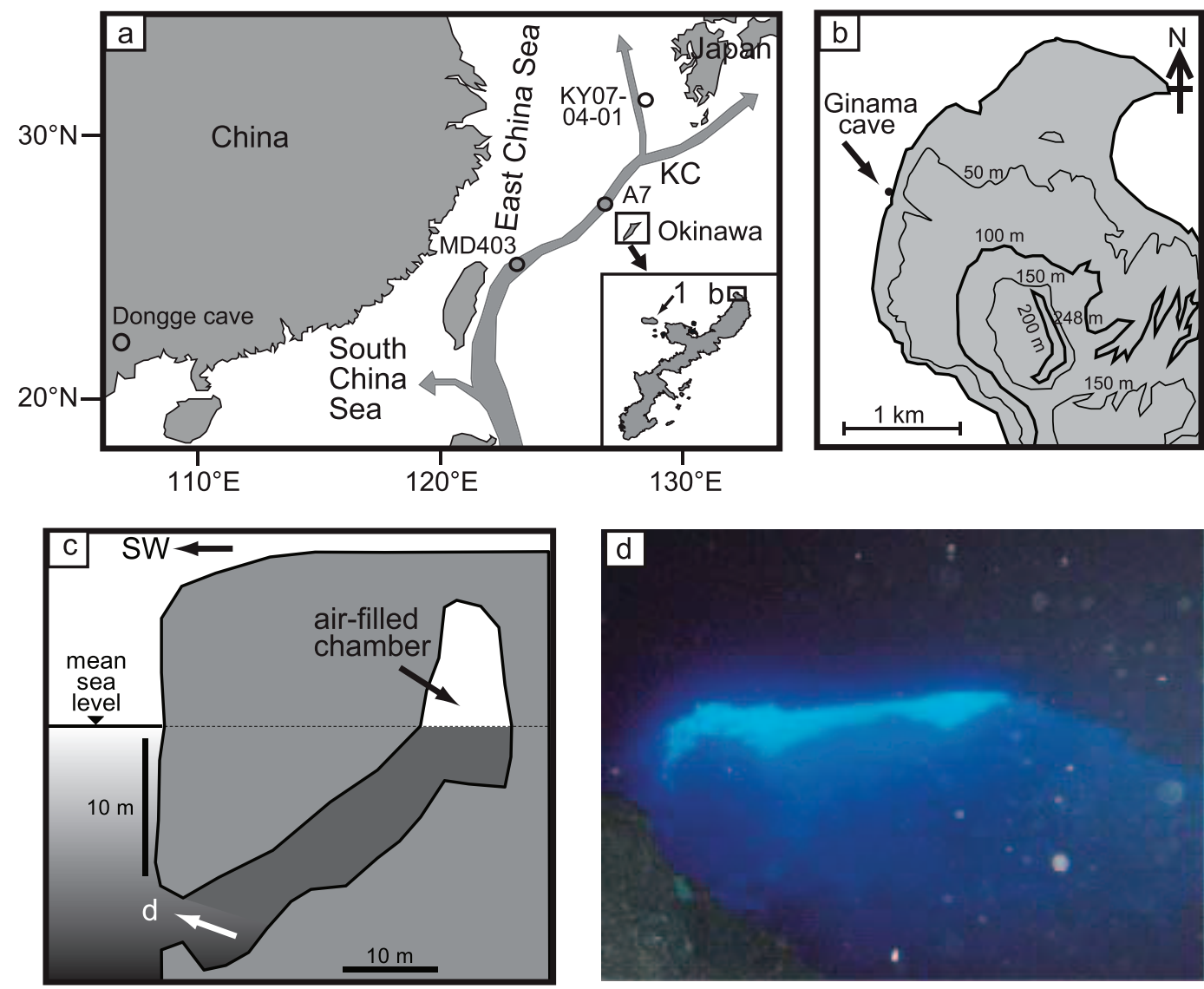

Figure 1. (a) Location map of Okinawa, Japan, showing the locations of drill cores A7 (Sun et al., 2005; Xiang et al., 2007), MD403 (Lin et al., 2006), KY07-04-01 (Kubota et al., 2010), and Dongge Cave (Wang et al., 2005); KC: Kuroshio Current; inset, area of part (b) and 1: Daidokutsu Cave off Ie Island. (b) Location map of submarine cave Ginama on the northern tip of Okinawa. (c) Simplified cross-section of the cave. Note vertical exaggeration. The white arrow shows the direction of the view in (d). (d) Photograph of the cave entrance, looking outward from inside the cave.

by sea cliffs with a height of approximately $10 \mathrm{~m}$. The entrance to the cave, which is approximately $15-\mathrm{m}$ below sea level, is $5 \mathrm{~m}$ high and $10 \mathrm{~m}$ wide. The cave consists of a narrow 40-m long upward-sloping gallery approximately $2 \mathrm{~m}$ high and $2 \mathrm{~m}$ wide and a dark, inner air-filled chamber with a height of $15 \mathrm{~m}$ (Fig. 1c). Many stalagmites are present both above and below the water surface in the inner chamber.

No emergent coastal landforms are present in the area, suggesting no net uplift of the area during the Holocene. The subsidence rate of the study area is currently $0.04 \mathrm{~mm} \mathrm{y}^{-1}$, based on geographic records from 1979 to 2006 (Geographical Survey Institute, 2007). Hongo and Kayanne (2010) reconstructed the Holocene sea level curve based on coral reefs of Ishigaki Island, Ryukyu Islands, which is located approximately $500 \mathrm{~km}$ southwest of the present study area. Based on the reconstruction, the entrance to Ginama Cave is thought to have become submerged at approximately 8000 years BP. To the best of our knowledge, no researches have been conducted on local groundwater, and no water wells are present in the area.

\section{Methods}

Water temperature and salinity were measured outside Ginama Cave close to the sea surface and in the pool below the chamber at $1 \mathrm{~m}$ intervals from the surface of the pool to a depth of $12 \mathrm{~m}$; all measurements were obtained on 10 July 2012 . We carefully observed and recorded all mega-fossils of sessile organisms on the rock wall of the cave pool at depths shallower than $10 \mathrm{~m}$ on $12-14$ October 2011 and again on 10-11 July 2012, at which time we collected fossil shells of three individuals of the coralline sponge Acanthocaetetes wellsi and ten individuals of the bivalve Pycnodonte taniguchii. Both species are sessile organisms that live in submarine cave or cryptic habitats (Jackson et al., 1971; Jackson and Winston, 1982; Hayami and Kase, 1992). The bivalve $P$. taniguchii attaches to hard substrates with a thickened left valve (Hayami and Kase, 1992). The shells of both A. wellsi and P. taniguchii are composed of $100 \%$ calcite (Hayami and Kase, 1992; Reitner and Gautret, 1996). Many sessile micro-bivalves, most of which are less than $5 \mathrm{~mm}$ in length, such as Cosa 


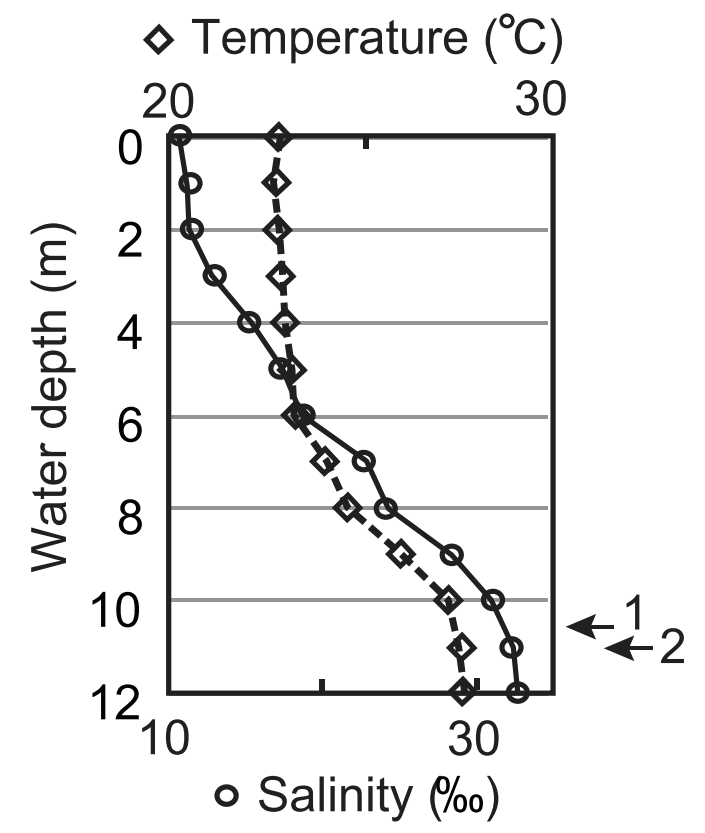

Figure 2. Water temperature and salinity in Ginama Cave, showing the water depth of the upper limit of living individuals of the bivalve Pycnodonte taniguchii (1) and of the coralline sponges Acanthocaetetes wellsi (2).

waikikia, Cosa kinjoi, and Parvamussium crypticum are present in the submarine caves of Okinawa (Hayami and Kase, 1992). However, because these species attach to rock surfaces by means of a byssus, the shells drop off immediately after death. In this study, we did not investigate the sessile micro-bivalve species.

Collected fossil specimens were cut along the axis of maximum growth using a low-speed saw. The specimens were checked for diagenetic alteration using thin-section observations with an optical microscope. We determined radiocarbon ages of all thirteen specimens of $A$. wellsi and $P$. taniguchii. The samples were graphitized, and the target graphites were analyzed using accelerator mass spectrometry at the University of Tokyo, Japan. The results were corrected using a reservoir age of 400 years, and the ages were transformed to a calendar timescale using the program OxCal4.1 (Bronk Ramsey 2009), based on comparisons with Marine 13 data (Reimer et al. 2013), after applying a $\Delta R$ value for the Okinawa region of $29 \pm 18$ years (Yoneda et al., 2007).

\section{RESULTS}

Water temperatures and salinities in the pool increased with water depth (Fig. 2). At a depth of $12 \mathrm{~m}$, the values of both parameters were nearly equal to those of sea-surface water outside the cave.

A living individual of Acanthocaetetes wellsi was found at a water depth of $11.3 \mathrm{~m}$. We also found a young individual Pycnodonte taniguchii at a depth of $10.5 \mathrm{~m}$. Three fossil individuals of $A$. wellsi and ten fossil individuals of $P$. taniguchii (left valves only) were distributed at depths of up to $2.5 \mathrm{~m}$ within the brackish-water lens (Figs. 3 and 4). Thin-section observations show that these specimens were unaffected by diagenetic alteration, al-

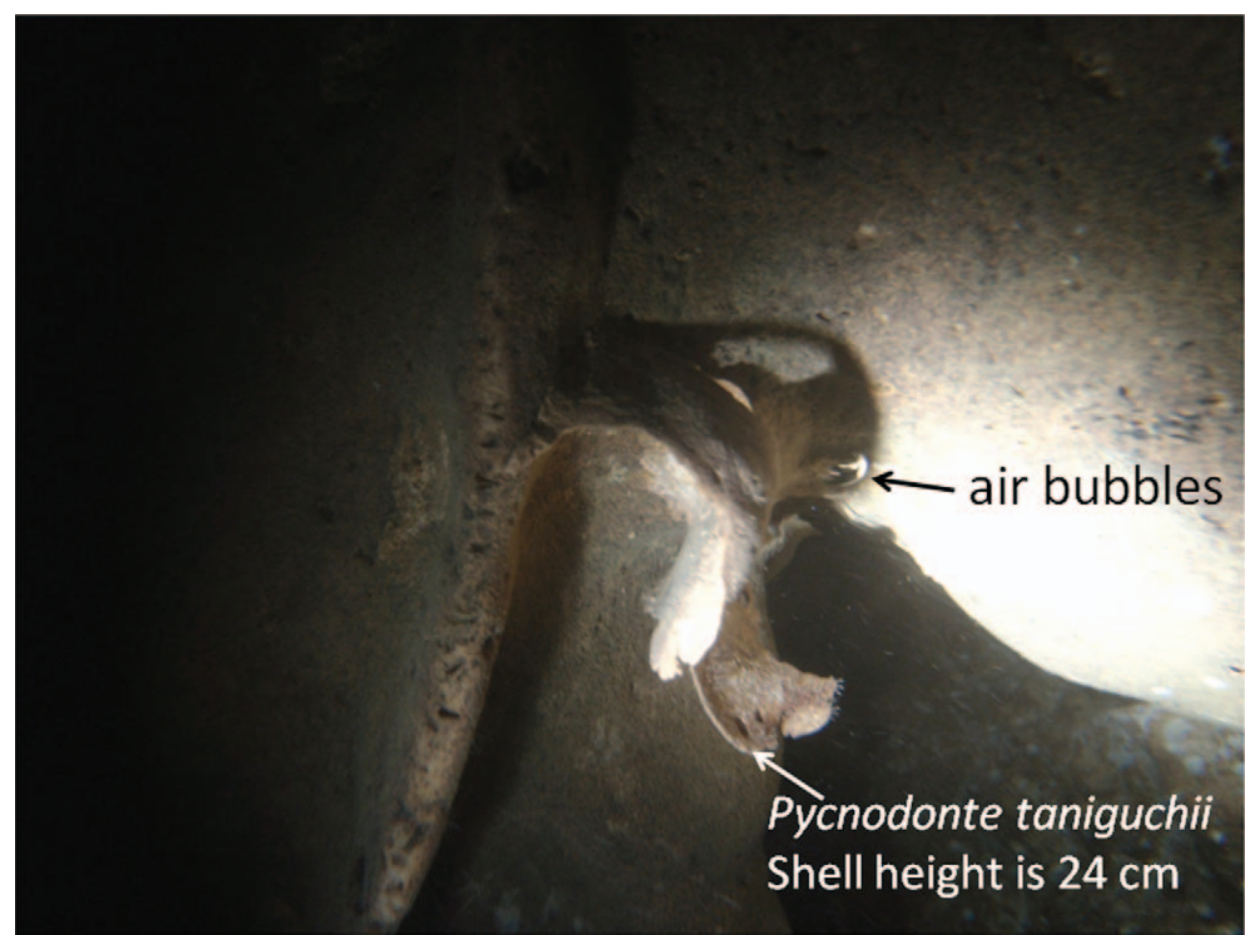

Figure 3. Photograph of a fossil of the bivalve Pycnodonte taniguchii (sample Ginama 9) at a water depth of $6.5 \mathrm{~m}$. 


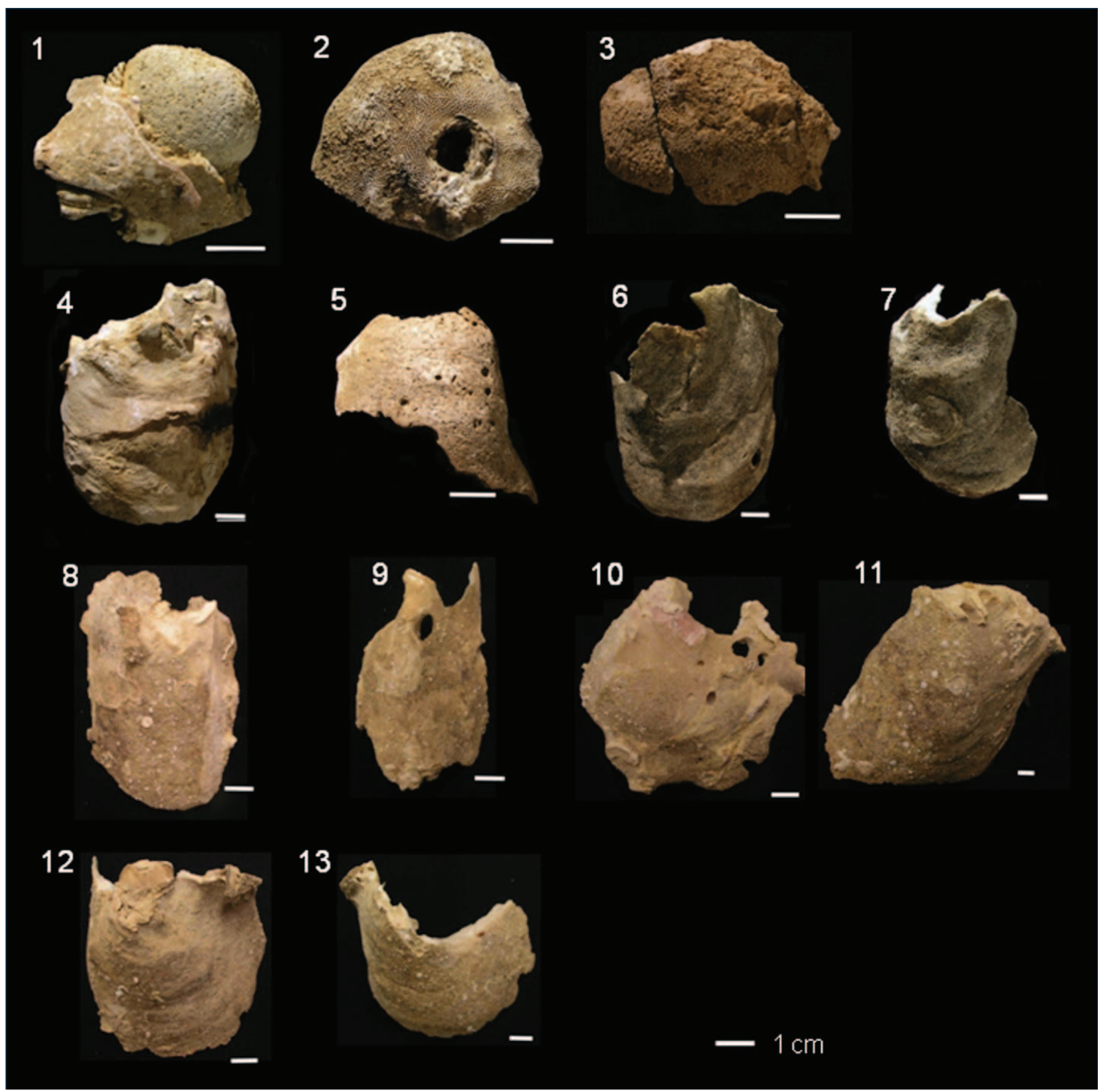

Figure 4. Photographs of specimens. 1-3: Acanthocaetetes wellsi (sample nos. Ginama 4-3, 6-1, 5-2). 4-13: Pycnodonte taniguchii 4-13; (samples Ginama 3, 8, 9, 10, 7-1, 7-2, 7-3, 19-1, 19-2, 19-3).

though a partially calcified filling can be observed on the surface layer of $A$. wellsi (Fig. 5a); this portion was excluded from ${ }^{14} \mathrm{C}$ dating. The radiocarbon ages obtained for the fossil specimens are listed in Table 1 and plotted in Figure 6. All specimens of $A$. wellsi and seven individuals of $P$. taniguchii fall into an older age group, from $5117 \pm 243(2 \sigma)$ to $3105 \pm 232(2 \sigma)$ cal years BP. Three individuals of $P$. taniguchii fall into a younger age group, from $566 \pm 75(2 \sigma)$ to $387 \pm 96(2 \sigma)$ cal years BP (Fig. 6).

\section{Discussion}

The coralline sponge Acanthocaetetes wellsi is a component of cryptic sessile communities on modern Indo-Pacific reefs (Reitner and Gautret, 1996). According to Grottoli (2006), the habitats of $A$. wellsi are unaffected by runoff from land. This species has also been collected in submarine caves on the southernmost coast of the Okinawa mainland and on Kume Island, Okinawa (Ohmori et al.,

Journal of Cave and Karst Studies, December 2014•167 

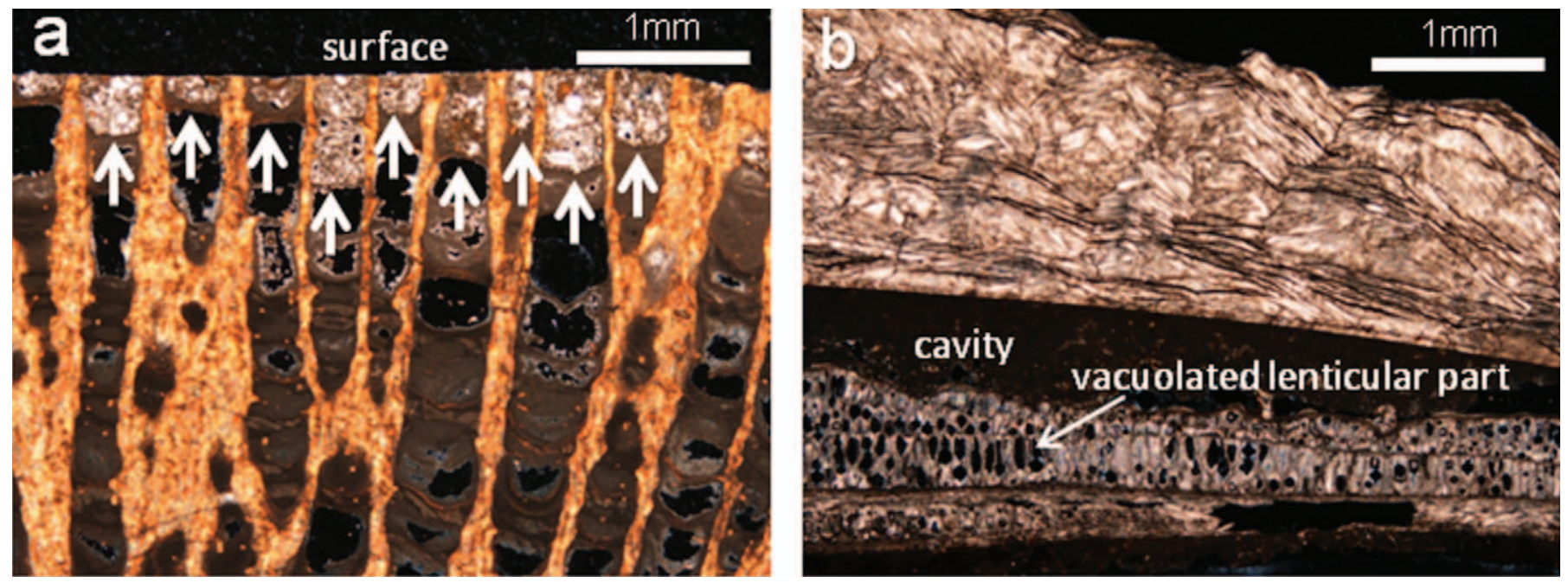

Figure 5. Thin-section photomicrographs (cross-polarized light). (a) Specimen of coralline sponge Acanthocaetetes wellsi (sample Ginama 4-3; age, $4623 \pm 206$ cal years BP); arrows show calcified fillings. (b) Specimen of the bivalve Pycnodonte taniguchii (sample Ginama 3; age, $5064 \pm 221$ cal years BP).

2008; Higa et al., 2010). None of the $A$. wellsi sites are reported to be influenced by runoff from land. We therefore think that $A$. wellsi thrives in conditions of normal salinity. To our knowledge, the Ginama Cave is the northernmost cave in which $A$. wellsi has been found.

Live individuals of the bivalve $P$. taniguchii have been found at many cavernicolous sites of the following islands in the western Pacific and eastern regions of the Indian Ocean: Ryukyu (Miyako, Okinawa, and Yonaguni islands), Bonin, Palau, Philippines (Luzon, Cebu, Bohol islands), Malaysia, Vanuatu, Fiji, Tonga and Thailand (near Phuket) (Hayami and Kase, 1992, 1999). According to Hayami and Kase (1992, 1999), individuals of $P$. taniguchii always grow under conditions of normal salinity and temperature. Ginama Cave and Daidokutsu Cave, located approximately $45 \mathrm{~km}$ southwest of the study area off Ie Island (Fig. 1a), are among the northernmost sites at which $P$. taniguchii has been found. According to Yamamoto et al. (2010), seasonal changes in water temperature in Daidokutsu Cave range from $29{ }^{\circ} \mathrm{C}$ in August-September to $21{ }^{\circ} \mathrm{C}$ in February. Data from the Japan Oceanographic Data Center (2007) show that, at water depths of $20 \mathrm{~m}$, similar to those of the study area, water temperatures range from $28.2 \pm 0.6{ }^{\circ} \mathrm{C}$ in September to 22.0 $\pm 0.9^{\circ} \mathrm{C}$ in February, which indicates that $P$. taniguchii can survive at temperature of $21^{\circ} \mathrm{C}$ during the winter season. No studies have reported on the lower limits of dissolve oxygen for the survival of either $A$. wellsi or $P$. taniguchii.

As noted above, living individuals of $A$. wellsi and $P$. taniguchii were found in Ginama Cave at depths of $11.3 \mathrm{~m}$ and $10.5 \mathrm{~m}$, respectively. At depths shallower than $10 \mathrm{~m}$, both water temperature and salinity decrease upward. It is therefore likely that relatively low temperatures and

Table 1. Results of ${ }^{14} \mathrm{C}$ dating; uncertainties are $2 \sigma$.

\begin{tabular}{llccc}
\hline Sample Number & \multicolumn{1}{c}{ Sample } & Depth, $\mathrm{m}$ & Conventional ${ }^{14} \mathrm{C}$ Age, BP & Calendar Age Ranges, cal BP \\
\hline Ginama 4-3 & Acanthocaetetes wellsi & 2.5 & $4491 \pm 83$ & $4623 \pm 206$ \\
Ginama 6-1 & Acanthocaetetes wellsi & 4.2 & $4863 \pm 85$ & $5117 \pm 243$ \\
Ginama 5-2 & Acanthocaetetes wellsi & 5.1 & $3454 \pm 83$ & $3279 \pm 222$ \\
Ginama 3 & Pycnodonte taniguchii & 4.0 & $4814 \pm 86$ & $5064 \pm 221$ \\
Ginama 8 & Pycnodonte taniguchii & 5.5 & $3966 \pm 85$ & $3932 \pm 247$ \\
Ginama 9 & Pycnodonte taniguchii & 6.5 & $4356 \pm 86$ & $4474 \pm 271$ \\
Ginama 10 & Pycnodonte taniguchii & 6.5 & $4304 \pm 82$ & $4394 \pm 251$ \\
Ginama 7-1 & Pycnodonte taniguchii & 8.3 & $4622 \pm 88$ & $4806 \pm 262$ \\
Ginama 7-2 & Pycnodonte taniguchii & 8.3 & $3313 \pm 86$ & $3105 \pm 232$ \\
Ginama 7-3 & Pycnodonte taniguchii & 8.3 & $4591 \pm 158$ & $4779 \pm 439$ \\
Ginama 19-1 & Pycnodonte taniguchii & 9.7 & $784 \pm 47$ & $387 \pm 96$ \\
Ginama 19-2 & Pycnodonte taniguchii & 9.7 & $996 \pm 46$ & $566 \pm 75$ \\
Ginama 19-3 & Pycnodonte taniguchii & 9.7 & $896 \pm 43$ & $489 \pm 86$ \\
\hline
\end{tabular}



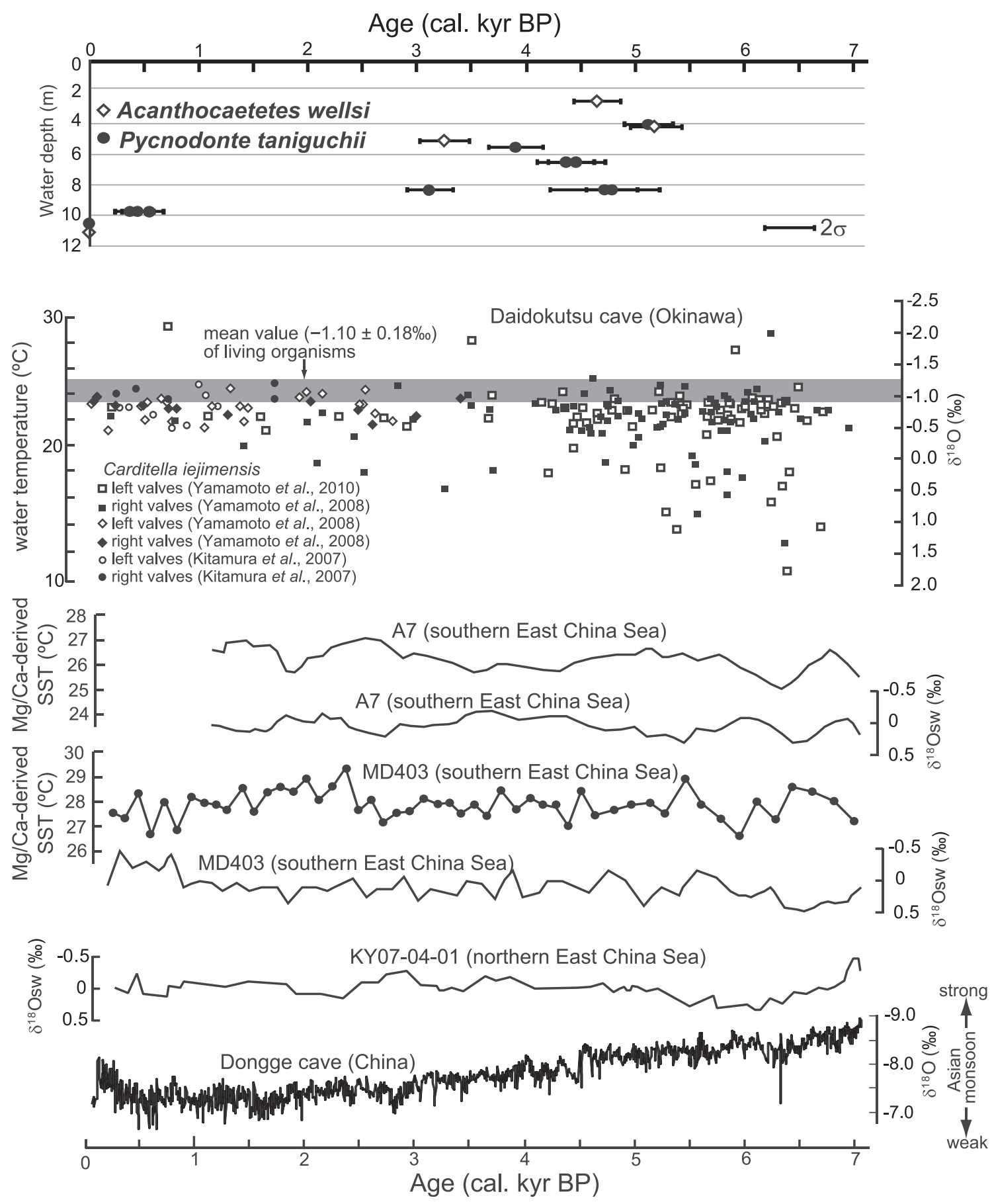

Figure 6. Top: Age data for fossils from this paper. Middle: $\delta^{18} \mathrm{O}$ and corresponding temperature values of Carditella iejimensis shells from cored samples (Kitamura et al., 2013). Bottom: On common scale $\mathrm{Mg} / \mathrm{Ca}$-derived SSTs and $\delta^{18} \mathrm{O}_{\text {sw }}$ records from cores A7 (Sun et al., 2005), MD403 (Lin et al., 2006), and KY07-04-01 (Kubota et al., 2010) and stalagmite $\delta^{18} \mathrm{O}$ records from Dongge Cave, southeast China (Wang et al., 2005). The locations of all sites are shown in Figure 1.

salinities prevented these sessile marine organisms from colonizing surfaces at depths shallower than $10 \mathrm{~m}$. On the other hand, ${ }^{14} \mathrm{C}$ ages obtained in the present study show that fossil specimens of $A$. wellsi and $P$. taniguchii are present at depths shallower than $10 \mathrm{~m}$. According to Hongo and Kayanne (2010), a mid-Holocene highstand occurred at approximately $5000 \mathrm{cal}$. years BP, at a level of approximately $3 \pm 2.5 \mathrm{~m}$ above present mean sea level, based on vertical distributions of corals on Ishigaki Island, Okinawa. At approximately 5000 cal. years BP, A. wellsi (sample no. Ginama 6-1) and P. taniguchii (sample no. Ginama 3) were distributed at depths of 4.0 and $4.2 \mathrm{~m}$, 
respectively (Table 1). Assuming that the rate of subsidence during the past 5000 years equals the present day surveyed rate of $0.04 \mathrm{~mm} /$ year, the total subsidence during this period is estimated to be $0.2 \mathrm{~m}$. Based on this subsidence rate and sea level at approximately $5000 \mathrm{cal}$. years $\mathrm{BP}(3 \pm 2.5 \mathrm{~m}$ above present mean sea level), the estimated depths of $A$. wellsi and $P$. taniguchii were from 4.3 to $9.5 \mathrm{~m}$, and from 4.5 to $9.7 \mathrm{~m}$, respectively. From $566 \pm 75$ to $387 \pm 96$ cal years BP, the upper limit of survival of individuals of $P$. taniguchii (depth, $9.7 \mathrm{~m}$; sample nos Ginama 19-1, -2, and -3) was shallower than that of presently living individuals. We therefore suggest that the influence of fresh water in the Ginama Cave pool at the present day is the strongest it has been in the past 5000 years, although we note that data are missing for the period 3105-566 cal years BP. In addition, changes in the flux of fresh water into the cave cannot be explained by relative sea level changes.

The rainy season in the study area occurs during the summer monsoon. Precisely dated stalagmite oxygenisotope records from China reveal that a Holocene weakening of the summer monsoon since 7000 years BP corresponds to an orbitally induced reduction in summertime solar insolation in the Northern Hemisphere (e.g., Dykoski et al., 2005; Wang et al., 2005) (Fig. 2). Such a weakening of the summer monsoon should cause a decrease in the flux of fresh water into the cave.

Many studies have examined Holocene oceanographic changes in the East China Sea, based on geochemical analyses of the planktonic foraminifera Globigerinoides ruber, which remains at water depths of 2 to $50 \mathrm{~m}$ during its life cycle (e.g., Fairbanks et al., 1982; Hemleben et al., 1989; Lin et al., 2004) and were recovered from deep-sea sedimentary cores (Jian et al., 2000; Ijiri et al., 2005; Sun et al., 2005; Lin et al., 2006; Kubota et al., 2010). Sun et al. (2005), Lin et al. (2006), and Kubota et al. (2010) reported no changes in sea-surface temperatures or sea-surface salinities in the East China Sea during the past 7000 years. Jian et al. (2000) proposed that a decrease in temperatures during the period 4600-2700 cal. years BP was related to an intensification of the winter monsoon, although they reported no changes in temperatures or salinities during the past 2700 years.

Yamamoto et al. (2010) measured $\delta^{18} \mathrm{O}$ values of fossils of the micro-bivalve Carditella iejimensis, which have height and length $<3.5 \mathrm{~mm}$ and dwell on the sediment surface (Hayami and Kase, 1993), from core sediments collected from Daidokutsu Cave, Ie Island, Okinawa. The results also show no clear long-term trends in the $\delta^{18} \mathrm{O}$ values of bivalves during the past 7000 years. More recently, Kitamura et al. (2013) analyzed $\delta^{18} \mathrm{O}$ values of 50 living $C$. iejimensis specimens from Daidokutsu Cave (Fig. 6) and concluded that the $\delta^{18} \mathrm{O}$ values represent the mean annual temperature and $\delta^{18} \mathrm{O}$ value of seawater. In summary, Kitamura et al. (2013) confirmed that no changes have occurred in either sea-surface temperatures or salinities during the past 7000 years. These results are consistent with the findings of previous studies in the East China Sea (Jian et al., 2000; Ijiri et al., 2005; Sun et al., 2005; Lin et al., 2006; Kubota et al., 2010).

Both oceanographic data and stalagmite oxygen isotope records show that a gradual weakening of the summer monsoon has not been a significant influence on seasurface temperatures and salinities in the area of Okinawa over the past 7000 years. Thus, the increased flux of fresh water to Ginama Cave cannot be explained by climate variables. Alternatively, we suggest that the development of crevices and passages within the cave caused the increase in the flux of fresh water over time. To test this interpretation, a further study should measure growth rates of stalagmites in the air chamber within the cave.

Our hypothesis is opposite to that proposed for nearby Daidokutsu Cave, which is that continuous filling of cavities within the reef foundation of the cave has influenced submarine cave communities (Yamamoto et al., 2009a; Omori et al., 2010). The difference between the two caves, that is, the possible development of cavities versus filling of cavities, indicates variability of millenniascale cavern forming processes in submarine caves caused by difference in their vertical position relative to sea level.

\section{ACKNOWLEDGEMENTS}

We greatly appreciate the assistance of Koushin Yasumura and Fumio Tamamura in the collection of samples. We thank two anonymous reviewers, whose comments and suggestions improved the original manuscript. We thank A. Stallard for improving the English in the manuscript. This study was funded by the Mitsubishi Foundation.

\section{REFERENCES}

Antonioli, F., Silenzi, S., and Frisia, S., 2001, Tyrrhenian Holocene palaeoclimate trends from spelean serpulids: Quaternary Science Reviews, v. 20, p. 1661-1670. doi:10.1016/S0277-3791(01)00012-9.

Böhm, F., Joachimski, M.M., Dullo, W-C., Eisenhauer, A., Lehnert, H., Reitner, J., and Wörheide, G., 2000, Oxygen isotope fractionation in marine aragonite of coralline sponges: Geochimica et Cosmochimica Acta, v. 64, p. 1695-1703. doi:10.1016/S0016-7037(99)00408-1.

Bronk Ramsey, C., 2009, Bayesian analysis of radiocarbon dates: Radiocarbon, v. 51, p. 337-360.

Chevaldonné, P., and Lejeusne, C., 2003, Regional warming-induced species shift in north-west Mediterranean marine caves: Ecology Letters, v. 6, p. 371-379. doi:10.1046/j.1461-0248.2003.00439.x.

Dorale, J.A., Onac, B.P., Fornós, J.J., Ginés, J., Ginés, A., Tuccimei, P., and Peatel, D.W., 2010, Sea-level highstand 81,000 years ago in Mallorca: Science, v. 327, p. 860-863. doi:10.1126/science.1181725.

Dykoski, C.A., Edwards, R.L., Cheng, Hai, Yuan, Daoxian, Cai, Yanjun, Zhang, Meiliang, Lin, Yushi, Qing, Jiaming, An, Zhisheng, and Revenaugh, J., 2005, A high-resolution, absolute-dated Holocene and deglacial Asian monsoon record from Dongge Cave, China: Earth and Planetary Science Letters, v. 233, p. 71-86. doi:10.1016/j.epsl. 2005.01.036.

Fairbanks, R.C., Sverdlove, M., Free, R., Wiebe, P.H., and Bé, A.W.H., 1982, Vertical distribution and isotopic fractionation of living planktonic foraminifer from the Panama Basin: Nature, v. 298, p. 841-844. doi:10.1038/298841a0. 
Geographical Survey Institute, 2007, Crustal Movements in the Kyushu and Okinawa Districts: Report of the Coordinating Committee for Earthquake Prediction, Japan, v. 78, p. 561-567 (in Japanese).

Grottoli, A.G., 2006, Monthly resolved stable oxygen isotope record in a Palauan sclerosponge Acanthocaetetes wellsi for the period of 19772001, in Suzuki, Y., Nakamori, T., Hidaka, M., Kayanne, H., Casareto, B.E., Nadaoka, K., Yamano, H., and Tsuchiya, M., eds., eds., Proceedings of the $10^{\text {th }}$ International Coral Reef Symposium: Tokyo, Japanese Coral Reef Society, p. 572-579.

Haase-Schramm, A., Böhm, F., Eisenhauer, A., Dullo, W-C., Joachimski, M.M., Hansen, B., and Reitner, J., 2003, Sr/Ca ratios and oxygen isotopes from sclerosponges: Temperature history of the Caribbean mixed layer and thermocline during the Little Ice Age: Paleoceanography, v. 18, no. 3, doi:10.1029/2002PA000830.

Hayami, I., and Kase, T., 1992, A new cryptic species of Pycnodonte from Ryukyu Islands: A living fossil oyster: Transactions and Proceedings of the Palaeontological Society of Japan, New Series, No. 165, p. $1070-1089$.

Hayami, I., and Kase, T., 1993, Submarine cave bivalvia from the Ryukyu Islands: systematics and evolutionary significance: The University Museum, The University of Tokyo, Bulletin 35, 133 p.

Hayami, I., and Kase, T., 1999, Geographic Distribution of Pycnodonte taniguchii: Newsletter of the Malacological Society of Japan, v. 30, p. 5-7 (in Japanese with English Abstract).

Hemleben, C., Spindler, M., and Anderson, O.R., 1989, Modern Planktonic Foraminifera: New York, Springer, $363 \mathrm{p}$.

Higa, K., Fukuyama, Y., Sekiya, M., West, R.R., Nagai, K., and Sugiyama, T., 2010, Habitat of a living fossil, Acanthocaetetes (Class Demospongiae), along the Komesu coast in the southern part of Okinawa Island: Fukuoka University Science Reports, v. 40, p. 233-243 (in Japanese).

Hongo, C., and Kayanne, H., 2010, Holocene sea-level record from corals: reliability of paleodepth indicators at Ishigaki Island, Ryukyu Islands, Japan: Palaeogeography, Palaeoclimatology, Palaeoecology, v. 287, p. 143-151. doi:10.1016/j.palaeo.2010.01.033.

Ijiri, A., Wang, Luejiang, Oba, T., Kawahata, H., Huang, Chen-Yue, and Huang, Chi-Yue, 2005, Paleoenvironmental changes in the northern area of the East China Sea during the past 42,000 years: Palaeogeography, Palaeoclimatology, Palaeoecology, v. 219, p. 239-261. doi:10.1016/j.palaeo.2004.12.028.

Ishibashi, T., 1974, On the Triassic Formation at Hedo-misaki in Okinawa-jima: The Journal of the Geological Society of Japan, v. 80, p. 329-330. (in Japanese).

Jackson, J.B.C., Goreau, T.F., and Hartman, W.D., 1971, Recent brachiopod-coralline sponge communities and their paleoecological significance: Science, v. 173, p. 623-625. doi:10.1126/science.173. 3997.623

Jackson, J.B.C., and Winston, J.E., 1982, Ecology of cryptic coral reef communities. I. Distribution and abundance of major groups of encrusting organisms: Journal of Experimental Marine Biology and Ecology, v. 57, p. 135-147. doi:10.1016/0022-0981(82)90188-5.

Japan Oceanographic Data Center, Online Data, 2007, http://jdoss1.jodc. go.jp/cgi-bin/1997/bts.jp. [Accessed October 10, 2013]

Jian, Zhimin, Wang, Pinxian, Saito, Y., Wang, Jiliang, Pflaumann, U., Oba, T., and Cheng, Xinrong, 2000, Holocene variability of the Kuroshio Current in the Okinawa Trough, northwestern Pacific Ocean: Earth and Planetary Science Letters, v. 184, p. 305-319. doi:10.1016/S0012-821X(00)00321-6.

Kitamura, A., Kobayashi, K., Tamaki, C., Yamamoto, N., Irino, T., Miyairi, Y., and Yokoyama, Y., 2013, Evidence of recent warming in the Okinawa region, subtropical northwestern Pacific, from an oxygen isotope record of a cave-dwelling marine micro-bivalve: Paleontological Research, v. 17, p. 58-68. doi:10.2517/1342-8144-17.1.58

Kitamura, A., Yamamoto, N., Kase, T., Ohashi, S., Hiramoto, M., Fukusawa, H., Watanabe, T., Irino, T., Kojitani, H., Shimamura, M., and Kawakami, I., 2007, Potential of submarine-cave sediments and oxygen isotope composition of cavernicolous micro-bivalve as a late Holocene paleoenvironmental record: Global and Planetary Change, v. 55, p. 301-316. doi:10.1016/j.gloplacha.2006.09.002

Kubota, Y., Kimoto, K., Tada, R., Oda, H., Yokoyama, Y., and Matsuzaki, H., 2010, Variations of East Asian summer monsoon since the last deglaciation based on $\mathrm{Mg} / \mathrm{Ca}$ and oxygen isotope of planktic foraminifera in the northern East China Sea: Paleoceanography, v. 25, PA4205, doi:10.1029/2009PA001891.
Lin, Hui-Ling., Wang, Wei-Chial, and Hung, Gwo-Wei, 2004, Seasonal variation of planktonic foraminiferal isotopic composition from sediment traps in the South China Sea: Marine Micropaleontology, v. 53, p. 447-460. doi:10.1016/j.marmicro.2004.08.004.

Lin, Yu-Shih, Wei, Kuo-Yen, Lin, In-Tian, Yu, Psi-Sen, Chiang, HongWei, Chen, Chen-Yin., Shen, Chaun-Chou, Mii, Homg-Sheng, and Chen, Yue-Gau., 2006, The Holocene Pulleniatina Minimum Event revisited: geochemical and faunal evidence from the Okinawa Trough and upper reaches of the Kuroshio current: Marine Micropaleontology, v. 59, p. 153-170. doi:10.1016/j.marmicro.2006.02.003.

Ohmori, K., Watanabe, T., Shirai, K., and Kan, H., 2008, Skeletal microstructures and the variety of trace elements in Pacific sclerosponges: Chikyu Monthly, v. 30, p. 322-328 (in Japanese).

Omori, A., Kitamura, A., Fujita, K., Honda, K., and Yamamoto, N., 2010, Reconstruction of light conditions within a submarine cave during the past 7,000 years based on the temporal and spatial distribution of algal symbiont-bearing large benthic foraminifers: Palaeogeography, Palaeoclimatology, Palaeoecology, v. 292, p. 443-452. doi:10.1016/j.palaeo.2010.04.004.

Parravicini, V., Guidetti, P., Morri, C., Montefalcone, M., Donato, M., and Bianchia, C.N., 2010, Consequences of sea water temperature anomalies on a Mediterranean submarine cave ecosystem: Estuarine, Coastal and Shelf Science, v. 86, p. 276-282. doi:10.1016/j.ecss. 2009.11.004.

Reimer, P.J., Bard, E., Bayliss, A., Beck, J.W., Blackwell, P.G., Bronk Ramsey, C., Buck, C.E., Cheng, Hai, Edwards, R.L., Friedrich, M., Grootes, P.M., Guilderson, T.P., Haflidason, H., Hajdas, I., Hatté, C., Heaton, T.J., Hoffmann, D.L., Hogg, A.G., Hughen, K.A., Kaiser, K.F., Kromer, B., Manning, S.W., Niu, M., Reimer, R.W., Richards, D.A., Scott, E.M., Southon, J.R., Staff, R.A., Turney, C.S.M., and van der Plicht, J., 2013, IntCal13 and Marine13 radiocarbon age calibration curves, $0-50,000$ years cal BP: Radiocarbon, v. 55, no. 4, p. 1869-1887. doi:10.2458/azu_js_rc.55.16947.

Reitner, J., and Gautret, P.P., 1996, Skeletal formation in the modern but ultraconservative chaeteid sponge Spirastrella (Acanthochaetetes) wellsi (Demospongiae, Porifera): Facies, v. 34, p. 193-207. doi:10.1007/BF02546164.

Sun, Youbin, Oppo, D.W., Xiang, Rong, Liu, Weiguo, and Gao, Shu, 2005, Last deglaciation in the Okinawa Trough: subtropical northwest Pacific link to Northern Hemisphere and tropical climate: Paleoceanography, v. 20, PA4005, doi:10.1029/2004PA001061.

Tuccimei, P., Soligo, M., Ginés, J., Ginés, A., Fornós, J., Kramers, J., and Villa, I.G., 2010, Constraining Holocene sea levels using U/Th ages of phreatic overgrowths on speleothems from coastal caves in Mallorca (Western Mediterranean): Earth Surface Processes and Landforms, v. 35, p. 782-790. doi:10.1002/esp. 1955.

van Hengstum, P.J., and Scott, D.B., 2011, Ecology of foraminifera and habitat variability in an underwater cave: distinguishing anchialine versus submarine cave environments: Journal of Foraminiferal Research, v. 41, p. 201-229. doi:10.2113/gsifr.41.3.201.

van Hengstum, P.J., and Scott, D.B., 2012, Sea-level rise and coastal circulation controlled Holocene groundwater development in Bermuda and caused a meteoric lens to collapse 1600 years ago: Marine Micropaleontology, v. 90-91, p. 29-43. doi:10.1016/j.marmicro.2012. 02.007 .

van Hengstum, P.J., Scott, D.B., Gröcke, D.R., and Charette, M.A., 2011, Sea level controls sedimentation and environments in coastal caves and sinkholes: Marine Geology, v. 286, p. 35-50. doi:10.1016/ j.margeo.2011.05.004

Wang, Yongjin, Cheng, Hai, Edwards, R.L., He, Yaoqi, Kong, Xinggong, An, Zhisheng, Wu, Jiangying, Kelly, M.J., Dykoski, C.A., and Li, Xiangdong, 2005, The Holocene Asian monsoon: links to solar changes and North Atlantic climate: Science, v. 308, p. 854-857. doi:10.1126/science.1106296.

Xiang, R., Sun, Y., Li, T., Oppo, D.W., Chen, M., and Zheng, F., 2007, Paleoenvironmental change in the middle Okinawa Trough since the last deglaciation: Evidence from the sedimentation rate and planktonic foraminiferal record. Palaeogeography, Palaeoclimatology, Palaeoecology 243, p. 378-393. doi:10.1016/j.palaeo.2006.08.016.

Yamamoto, N., Kitamura, A., Irino, T., Kase, T., and Ohashi, S., 2008, Reconstruction of paleotemperatures in Northwest Pacific over the past 3,000 years from $\delta^{18} \mathrm{O}$ values of the micro-bivalvia Carditella iejimensis found in a submarine cave: Global and Planetary Change, v. 62 , p. 97-106. doi:10.1016/j.gloplacha.2007.12.001. 
Yamamoto, N., Kitamura, A., Irino, T., Kase, T., and Ohashi, S., 2010, Climatic and hydrologic variability in the East China Sea during the last 7,000 years based on oxygen isotope records of the submarine cavernicolous micro-bivalve Carditella iejimensis: Global and Planetary Change, v. 72, p. 131-140. doi:10.1016/j.gloplacha.2010.01.025.

Yamamoto, N., Kitamura, A., Ohmori, A., Morishima, Y., Toyofuku, T., and Ohashi, S., 2009a, Long-term changes in sediment type and cavernicolous bivalve assemblages in Daidokutsu submarine cave, Okinawa Islands: evidence from a new core extending over the past 7,000 years: Coral Reefs, v. 28, p. 967-976. doi:10.1007/s00338-009-0536-2.
Yamamoto, N., Sakai, S., and Kitamura, A., 2009b, Evaluation of the $\delta^{18} \mathrm{O}$ value of the submarine cavernicolous micro-bivalve Carditella iejimensis as a proxy for palaeotemperature: Paleontological Research, v. 13 , p. 279-284. doi:10.2517/1342-8144-13.3.279.

Yoneda, M., Uno, H., Shibata, Y., Suzuki, R., Kumamoto, Y., Yoshida, K., Sasaki, T., Suzuki, A., and Kawahata, H., 2007, Radiocarbon marine reservoir ages in the western pacific estimated by prebomb molluscan shells: Nuclear Instruments and Methods in Physics Research B: Beam Interactions with Materials and Atoms, v. 259, p. 432-437. doi:10.1016/j.nimb.2007.01.184. 